\title{
Palaeobiogeography, palaeoecology and evolution of Lower Ordovician conulariids and Sphenothallus (Medusozoa, Cnidaria), with emphasis on the Fezouata Shale of southeastern Morocco
}

\author{
Heyo Van Iten a,b,*, Lucy Muir ${ }^{c}$, Marcello G. Simões ${ }^{\mathrm{d}}$, Juliana M. Leme ${ }^{\mathrm{e}}$, Antonio C. Marques ${ }^{\mathrm{f}, \mathrm{g}}$, Naomi Yoder ${ }^{\mathrm{h}}$ \\ a Department of Geology, Hanover College, Hanover, IN 47243, USA \\ b Cincinnati Museum Center, Department of Invertebrate Paleontology, 1301 Western Avenue, Cincinnati, OH 45203, USA \\ c Department of Geology, Amgueddfa Cymru - National Museum of Wales, Cathays Park, Cardiff CF10 3NP, Wales, UK \\ d Department of Zoology, São Paulo State University, Rubião Junior District, 18618-000 Botucatu, São Paulo, Brazil \\ e Geosciences Institute, University of São Paulo, R. Lago 562, 05508-080, São Paulo, Brazil \\ ${ }^{\mathrm{f}}$ Biosciences Institute, University of São Paulo, R. Matão 101, 05508-090 São Paulo, Brazil \\ g Center for Marine Biology, University of São Paulo, São Sebastião, Brazil \\ ${ }^{\mathrm{h}}$ Department of Marine Science, University of Southern Mississippi, Stennis Space Center, MS 39529, USA
}

\section{A R T I C L E I N F O}

\section{Article history:}

Received 31 August 2015

Received in revised form 4 March 2016

Accepted 10 March 2016

Available online 15 March 2016

\section{Keywords:}

Conulariids

Sphenothallus

Medusozoa

Lower Ordovician

Gondwana

Fezouata

\begin{abstract}
A B S T R A C T
The fossil record of conulariids (Cnidaria, Scyphozoa) extends downward into the topmost part of the Ediacaran System, but the first appearance of diverse, widespread conulariids is in siliciclastic rock units of Early Ordovician age, which collectively host at least six conulariid genera. Some of these same units also contain Sphenothallus, a probable medusozoan that frequently co-occurs with conulariids in Ordovician and younger deposits. Lower Ordovician conulariid localities are distributed among five (originally) Southern Hemisphere terranes, namely Core Gondwana (Archaeoconularia, Eoconularia and Teresconularia), Armorica (Conularia azaisi), Avalonia (Archaeoconularia, Eoconularia and Exoconularia), Perunica (Archaeoconularia, Conularia and Conulariella) and South China (Conulariella). C. azaisi, currently known from the Southern Montagne Noire (France), probably represents a new genus. Sphenothallus occurs in South China, North China (Korea), Armorica (Southern Montagne Noire) and Core Gondwana (Morocco). In southeastern Morocco, Burgess Shale-type Konservat-Lagerstätten in the Fezouata Shale (Tremadocian-Floian) yield Archaeoconularia sp., Eoconularia sp. and at least one species of Sphenothallus. This low-diversity conulariid assemblage is most similar to the Tremadocian assemblage of Wales (Avalonia), which likewise consists of a single species each of Archaeoconularia and Eoconularia. In the Fezouata Shale, Archaeoconularia sp. and Eoconularia sp. frequently occur in monospecific mass associations. Such associations probably represent an original clumped distribution on the seafloor. Additionally, some Eoconularia sp. occur in V-like pairs or radial clusters, and also some specimens were attached at the apical end to a phosphatic brachiopod or to a corner sulcus of a larger specimen of Eoconularia sp. Similar conulariid/ brachiopod associations, consisting of Conularia trentonensis and Onniella sp., occur in the Upper Ordovician (Katian) Collingwood Shale of southern Ontario, Canada.
\end{abstract}

(C) 2016 Elsevier B.V. All rights reserved.

\section{Introduction}

Conulariids (order Conulariida Miller and Gurley, 1896) and Sphenothallus Hall, 1847, two extinct groups of medusozoan cnidarians that produced a finely lamellar, organo-phosphatic periderm (Van Iten et al., 1992, 2006a), first appear in the uppermost Ediacaran and lower

\footnotetext{
* Corresponding author at: Department of Geology, Hanover College, Hanover, IN 47243, USA.

E-mail addresses: vaniten@hanover.edu (H. Van Iten), lucy@asoldasthehills.org (L. Muir), profmgsimoes@gmail.com (M.G. Simões), leme@usp.br (J.M. Leme), marques@ib.usp.br (A.C. Marques), naomi.yoder@eagles.usm.edu (N. Yoder).
}

Cambrian systems, respectively (e.g. Zhu et al., 2000; Li et al., 2004; Van Iten et al., 2014a). Sphenothallus has been reported widely from the Cambrian System (see for example Fatka and Kraft, 2013; Muscente and Xiao, 2015), but thus far Cambrian conulariids are represented solely by Baccaconularia Hughes et al., 2000 from the Furongian Saint Lawrence Formation (Upper Mississippi Valley, USA), though conulariids may occur in Cambrian Stage 1 (see Van Iten et al., 2010 and references cited therein), and Paraconularia sp. has been found in the latest Ediacaran Tamengo Formation of Brazil (Van Iten et al., 2014a). The last occurrence is particularly intriguing as recent cladistic analyses (Leme et al., 2008; Van Iten et al., 2014b) posit that Paraconularia Sinclair, 1940 was a relatively apical branch on the conulariid tree. In a number of Ordovician and younger rock units, 
conulariids and Sphenothallus occur in close association with each other, in some cases in relatively restricted facies in which normal marine benthos such as corals, crinoids and rhynchonelliform brachiopods are rare or absent (e.g. Van Iten et al., 1996, 2012). Thus, in addition to possibly being closely related to each other phylogenetically, conulariids and Sphenothallus may have shared similar palaeoenvironmental preferences.

The first appearance of multiple genera of conulariids, in localities throughout much of the world, is in Lower Ordovician formations, some of which also host Sphenothallus (Table 1). Interestingly, all currently known Lower Ordovician conulariids and Sphenothallus are from (originally) Southern Hemisphere terranes and localities, predominantly Gondwanan and peri-Gondwanan, which, with the exception of North China, generally were situated at mid- to very high palaeolatitudes (Cocks and Torsvik, 2004). In part this may reflect the fact that the Lower Ordovician rock records of the relatively few low-latitude terranes such as Laurentia are dominated by sparsely fossiliferous dolostones deposited in restricted environments (e.g. Overstreet et al., 2003), suggesting that the lack of conulariids and Sphenothallus in these regions may be, at least to some extent, caused by palaeoenvironmental or taphonomic artifacts. The most recent discoveries of Lower Ordovician conulariids are in the Santa Victoria Group of northwestern Argentina (Teresconularia; Leme et al., 2003), the Tonggao Formation of Guizhou Province, South China (Conulariella; Van Iten et al., 2013), and the Fezouata Shale of southeastern Morocco (Van Roy et al., 2015). In the last two formations, conulariids co-occur with Sphenothallus. The Tremadocian-Floian Fezouata Shale contains two exceptionally preserved fossil intervals (EPFs) yielding soft-bodied arthropods and other taxa, some of which were originally described from Burgess Shale-type biotas of early or middle Cambrian age (Van Roy et al., 2010; Martin et al., in press). Sphenothallus and two species of conulariids collectively occur in both of these intervals, one of which (60 $\mathrm{m}$ thick) occurs in the lower part of the formation and is late Tremadocian in age, and the other of which (15 m thick) occurs in the upper part and is mid Floian in age (Gutiérrez Marco and Martin, 2016-in this issue). Many Burgess Shale-type Cambrian faunas have been sampled intensively, yielding tens of thousands of exceptionally well-preserved fossils ranging from micro-invertebrates to chordates (e.g. Caron and Jackson, 2008; Zhao et al., 2010). Sphenothallus sp. is extremely rare in the mid Cambrian Burgess Shale (British Columbia, Canada; Van Iten et al., 2002), but to date neither this nor any other Cambrian Konservat-Lagerstätte has produced even a single conulariid.

The present article addresses key aspects of the distribution, palaeoecology and evolution of Lower Ordovician conulariids and Sphenothallus, in the context of a parsimony-based cladistic hypothesis of phylogenetic relationships among conulariid genera (Fig. 1). We pay particular attention to the Fezouata Shale, which at present is the only Ordovician rock unit in Africa known to contain conulariids and Sphenothallus. In addition to Burgess Shale-type organisms, the Fezouata Shale has yielded exceptionally preserved conulariids exhibiting evidence of original apical attachment to phosphatic brachiopods and conulariids apparently attached to other conulariid specimens.

\section{Material and methods}

The present study is based on review of the relevant literature and on direct examination of fossil specimens in collections of the following seven institutions: Department of Earth Sciences, Cadi Ayyad University, Marrakesh, Morocco (sample number prefix AA); Department of Earth Sciences, University of Lyon, France (sample number prefix UCBL-FSL); Department of Earth Sciences, Montpellier University, France (sample number prefix UM); National Museum of Wales (Cardiff, UK); Natural History Museum (London, UK); University of Michigan Museum of Paleontology (Ann Arbor, USA; specimen prefix number UMMP); and Yale University Peabody Museum (New Haven,

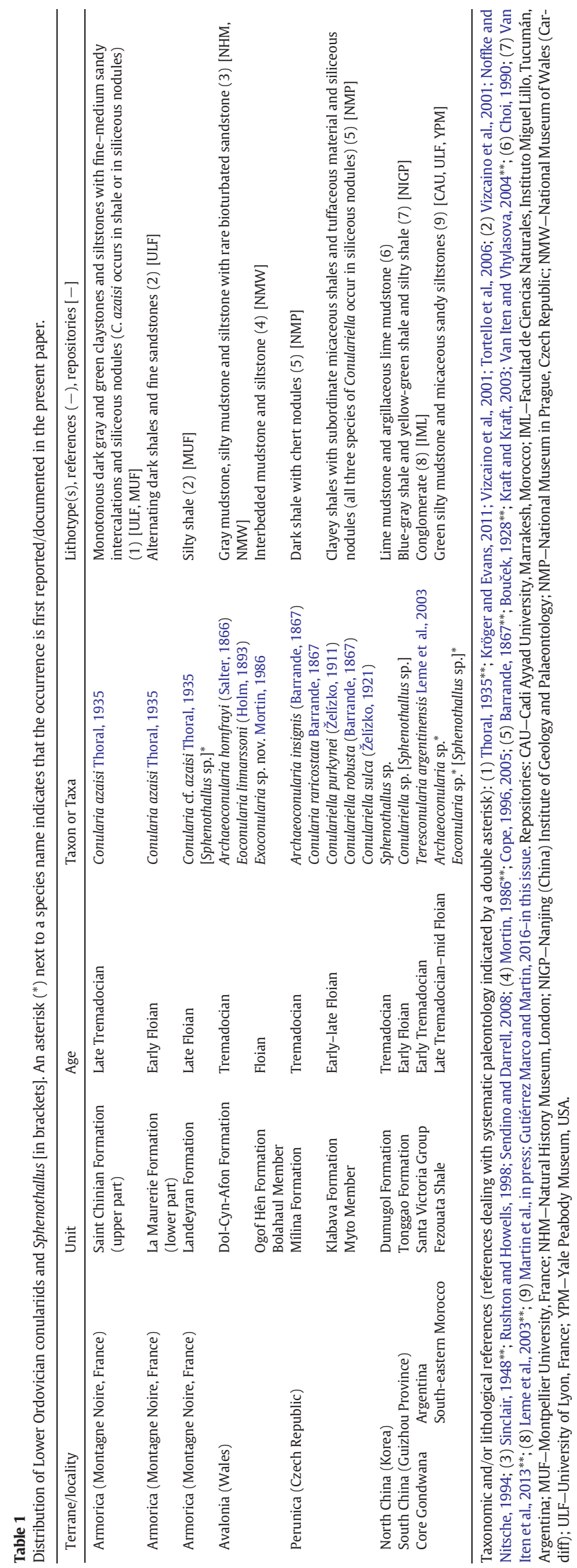




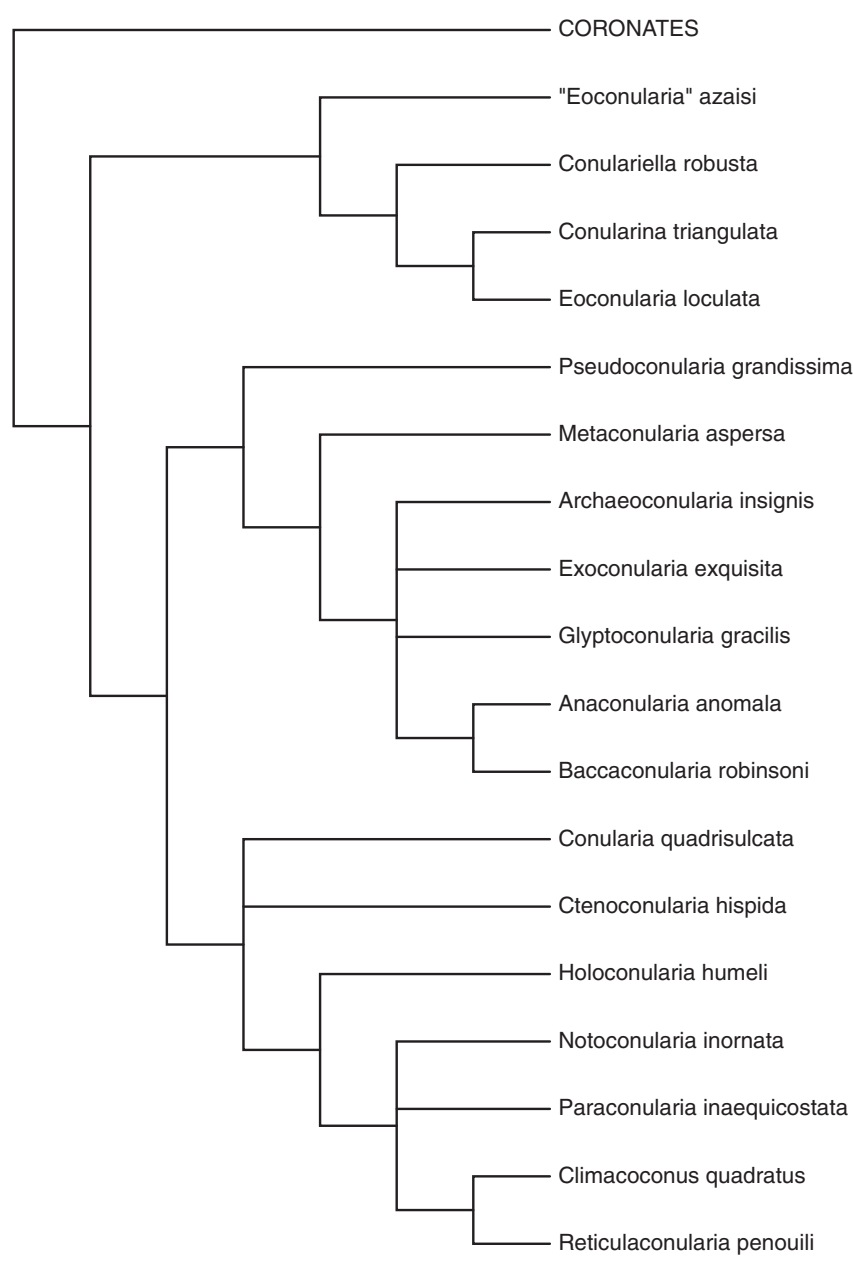

Fig. 1. Most parsimonious cladistic hypothesis of the phylogenetic relationships between 17 conulariid genera (represented by their type species) and Conularia azaisi Thoral, 1935 (length $=35$, consistency index $=0.514$, rescaled consistency index $=0.764$ ). Analysis based on 18 unweighted, binary characters of the periderm polarized using coronate scyphozoans as the outgroup (see Supplemental data).

Connecticut, USA; sample number prefix YPM). The most recent reports of Lower Ordovician conulariids and Sphenothallus are authored by one or more of the present investigators, and, with the exception of the Sphenothallus reported by Choi (1990), all other reports accepted here as valid were verified by direct examination of reposited specimens. Several of the occurrences tabulated here, namely Sphenothallus sp. from the Southern Montagne Noire (France) and this genus as well as two species of conulariids from the Fezouata Shale, are first reported in this article (Table 1). Material from the Fezouata Shale (approximately 500 examined specimens, primarily conulariids) was collected near the town of Zagora (Central Anti-Atlas) by field parties under the direction of B. Lefebvre (University of Lyon) and P. Van Roy (Ghent University (Belgium) and Yale University), during the course of multiple field seasons. Our phylogenetic analysis was conducted using PAUP* 4.0 b10 (Swofford, 2003) and followed the general procedures of Marques and Collins (2004), Collins et al. (2006) and Van Iten et al. (2006a, 2014b). Our character matrix is provided as Supplementary data.

\section{Lower Ordovician conulariids and Sphenothallus}

Together with Sphenothallus, Lower Ordovician strata have yielded six genera of conulariids: Archaeoconularia Bouček, 1939, Conularia
Miller in Sowerby, 1821, Conulariella Bouček, 1928, Eoconularia Sinclair, 1944, Exoconularia Sinclair, 1952 and Teresconularia Leme et al., 2003 (Figs. 2-4). Conularia azaisi Thoral, 1935 (Fig. 2A), originally described from the Saint Chinian Formation of the Southern Montagne Noire, France, has also been recorded from this region in the La Maurerie and Landeyran formations, and identified either as Eoconularia azaisi (La Maurerie Formation) or as E. cf. azaisi (Landeyran Formation) (Vizcaino et al., 2001, Fig. 3; this paper, Table 1). This assignment may have been based in part on the presence on the faces of this species of broad, sinusoidal transverse undulations similar to those of E. loculata (Wiman, 1895), the type species of the genus (Sinclair, 1944; see also illustrations in Jerre, 1994). However, the Southern Montagne Noire species differs from Conularia, Eoconularia and all other conulariids in possessing a raised midline crossed by very fine, trochoidal (long.) transverse ribs lacking nodes and interspace ridges (Van Iten, pers. obs.; this paper, Fig. 2A). Therefore, C. azaisi probably represents a new genus. Despite these differences, our cladistic analysis (Fig. 1), which revealed three major clades within Conulariida, places C. azaisi in the clade that includes Eoconularia, Conularina and Conulariella. This group is united by a single non-homoplasic synapomorphy, namely termination of the transverse ribs on the shoulders of the corner sulcus. The remaining Lower Ordovician conulariids collectively belong in the other two subclades, and thus all three major groups within Conulariida were in existence by early Ordovician times.

Recent chronostratigraphical revisions (e.g. Ebbestad and Högström, 2007) prove that several previous reports of Lower Ordovician conulariids were incorrectly dated. Thus, Sinclair (1948) and Hessland (1949) together listed Archaeoconularia, Conularia and Pseudoconularia as occurring in "Lower Ordovician" strata of Baltica (more specifically Sweden, Estonia and adjacent parts of Russia), which was located at mid-high palaeolatitudes within $15^{\circ}$ of Armorica and Perunica (Fig. 5). However, the rock units from which these conulariids were originally described, for example the "Gray Vaginatum Limestone" (= the Holen Formation; Ebbestad and Högström, 2007) and the "Orthoceras Limestone", have since been reassigned to the Middle Ordovician (see for example Ebbestad and Högström, 2007). Although Lower Ordovician marine deposits (e.g. the Latorp and Toyen formations; Ebbestad and Högström, 2007) are present in the Baltic Basin, as yet no conulariids have been found in these strata (Olle Hints, in litteris, 2015). Therefore, while Archaeoconularia and Conularia occur in Lower Ordovician rock units of other terranes (Table 1), Pseudoconularia, which was present and widespread in the Middle Ordovician Series (Van Iten and Vhylasova, 2004), is not currently known from Lower Ordovician strata. Finally, Sendino and Darrell (2008) listed Metaconularia cf. punctata (Slater, 1907) as occurring in Floian rocks in Wales. However, the specimens in question are from the Nant Ffrancon Subgroup, which is Middle Ordovician in age (Fortey et al., 2000).

Nearly all currently known Lower Ordovician conulariid localities are situated in Core Gondwana (Cocks and Torsvik, 2004) or in the peri-Gondwanan terranes of Armorica (Southern Montagne Noire), Avalonia (Wales) and Perunica (Bohemia), at high or very high palaeolatitudes (Fig. 5). One additional locality (Town of Sandu, Guizhou Province) is situated in South China, which lay astride $30^{\circ} \mathrm{S}$ in close proximity to Gondwanan India and the Arabian Shield (Cocks and Torsvik, 2013). Thus, nearly all known Lower Ordovician conulariid records were originally southward of $30^{\circ} \mathrm{S}$. Furthermore, all occurrences are in siliciclastic sediments, predominantly mudstones, siltstones and fine sandstones, in some cases micaceous or with siliceous concretions/nodules (Table 1). In addition to conulariids, four localities, namely southeastern Morocco, the Southern Montagne Noire (France), South China and Korea contain Sphenothallus (Table 1; Figs. 2B, 6A): of these localities, three (Morocco, France and South China) contain both Sphenothallus and conulariids. Sphenothallus was also reported from the Prague Basin, Bohemia (Perunica) by Mergl (1997), but as the material was not illustrated, we have been unable to verify this occurrence. 


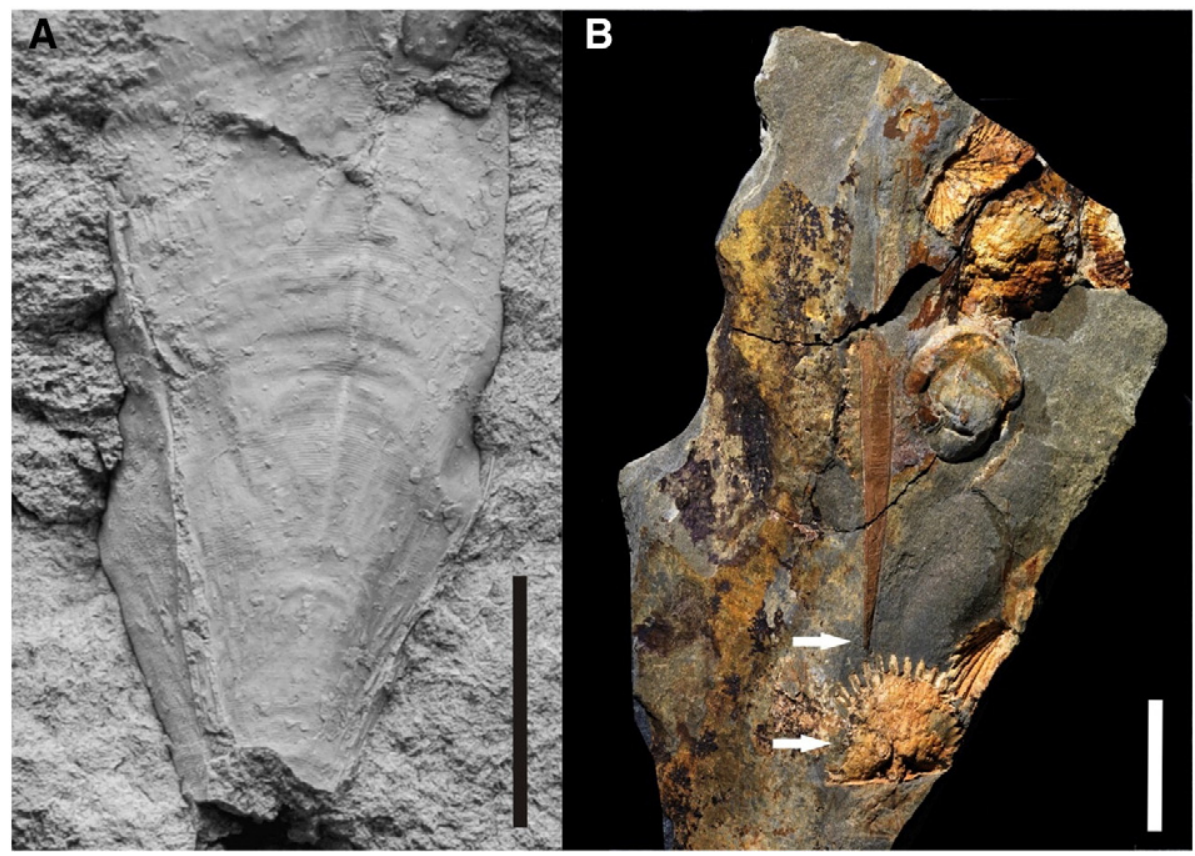

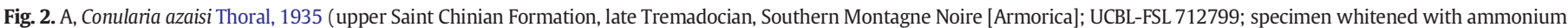

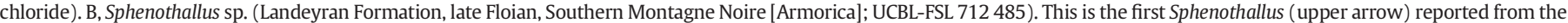
Lower Ordovician System of Armorica, and it may have been attached at its apical end (upper arrow) to a rhynchonelliform brachiopod (lower arrow). Scale bars $=10$ mm.

\section{Fezouata Shale (EPF-bearing intervals)}

\subsection{Conulariids}

At present the sole members of the phylum Cnidaria known to occur in the Fezouata Shale are Sphenothallus and conulariids, both sessile benthic medusozoans that were fully covered by a finely lamellar, organo-phosphatic periderm (Van Iten, 1992; Van Iten et al., 1992; Ford et al., in press). Destombes et al. (1985) were the first authors to report the presence of conulariids in the Fezouata Shale, but neither they nor subsequent authors (Van Roy et al., 2015) identified these fossils to lower taxonomical levels or reported the presence of Sphenothallus (though Van Roy et al., 2010 [fig. S2] misidentified their single illustrated Sphenothallus specimen as a "worm tube"). We here document the presence of one species each of Archaeoconularia and Eoconularia as well as at least one, possibly two, species of Sphenothallus.

Archaeoconularia sp. (Fig. 3A, B) and Eoconularia sp. (Figs. 3C-E, 4) are generally preserved flattened and aligned parallel to bedding, with nearly complete specimens preserving the gently arcuate apertural margin and tapering to within approximately $1 \mathrm{~mm}$ of the former apex. Comparisons of these specimens with previously described congeners from other terranes suggest that the Moroccan species are new. Specimens here identified as Archaeoconularia sp. (Fig. 3A, B) possess narrowly sulcate, non-thickened corners and midlines, and their faces exhibit minute, closely spaced nodes arranged in gently curving transverse rows that cross the midline without diminution or offset. From the corners the transverse rows trend toward the apical end of the periderm, but approximately half-way toward the midline they gradually change course to form shallow arcs that are convex toward the apertural end. While most specimens appear to have been on the order of $100-200 \mathrm{~mm}$ in length (Fig. 3B), one of the specimens examined in this study (YPM 530001) was originally at least $500 \mathrm{~mm}$ long. Relatively small specimens appear to be most similar to A. fecunda (Barrande, 1867) from the Upper Ordovician Zahořany Formation of Bohemia (Perunica) (Bouček, 1928), differing from this species in having the transverse node rows spaced farther apart. Specimens here identified as Eoconularia sp. (Fig. 3C-E, 4), originally $<50 \mathrm{~mm}$ long, exhibit a broad, shallow corner sulcus, commonly darker in color than the faces and slightly thickened internally, and their faces are crossed by smooth (non-nodose), non-thickened, sinusoidal (long.) transverse ribs similar to the primary transverse ribs of the type species, E. loculata (Holm, 1893) (see for example illustrations in Jerre, 1994). Features comparable to the finer, secondary transverse ribs of $E$. loculata were not discerned, but in any case these features were not noted in the original diagnosis of the genus (Sinclair, 1944).

\subsection{Sphenothallus}

The Fezouata Shale contains at least two species of more or less tubular fossils (Fig. 6), one of which can be assigned unequivocally to the genus Sphenothallus. Slender, straight to very gently curved specimens, here identified as Sphenothallus sp. 1 (Fig. 6A; see also Van Roy et al., 2010, fig. S2), exhibit the diagnostic pair of longitudinal thickenings situated at the end points of the tube's greatest diameter (Van Iten et al., 1992). Except for irregular, probably taphonomically induced wrinkling of the thin peridermal wall between the longitudinal thickenings, the tube appears to be smooth. In addition to the discovery of Sphenothallus in the Fezouata Shale, a smooth-walled specimen of this genus has been collected from the Landeyran Formation (late Floian) of the Southern Montagne Noire (Fig. 2B).

The other tubular fossil (Fig. 6B), which is likewise very gently tapered and with a subelliptical transverse crossection, nevertheless differs from non-ornamented Sphenothallus sp. 1 in exhibiting fine, regular, closely spaced transverse ridges or annulations that appear to fully encircle the tube. Also, development of the paired longitudinal thickenings appears to be very weak (and, again, the apical end is missing). For these reasons, we questionably assign this fossil to Sphenothallus, under the name ?Sphenothallus sp. 2.

\section{Lower Ordovician palaeobiogeography}

During Early Ordovician times, the peri-Gondwanan terranes of Armorica, Avalonia and Perunica lay in close proximity to each other and to Morocco (e.g. Nysæther et al., 2002; this paper, Fig. 5). It is not surprising, then, that Archaeoconularia is known from Tremadocian strata of Avalonia, Morocco and Perunica, or that Eoconularia has been 


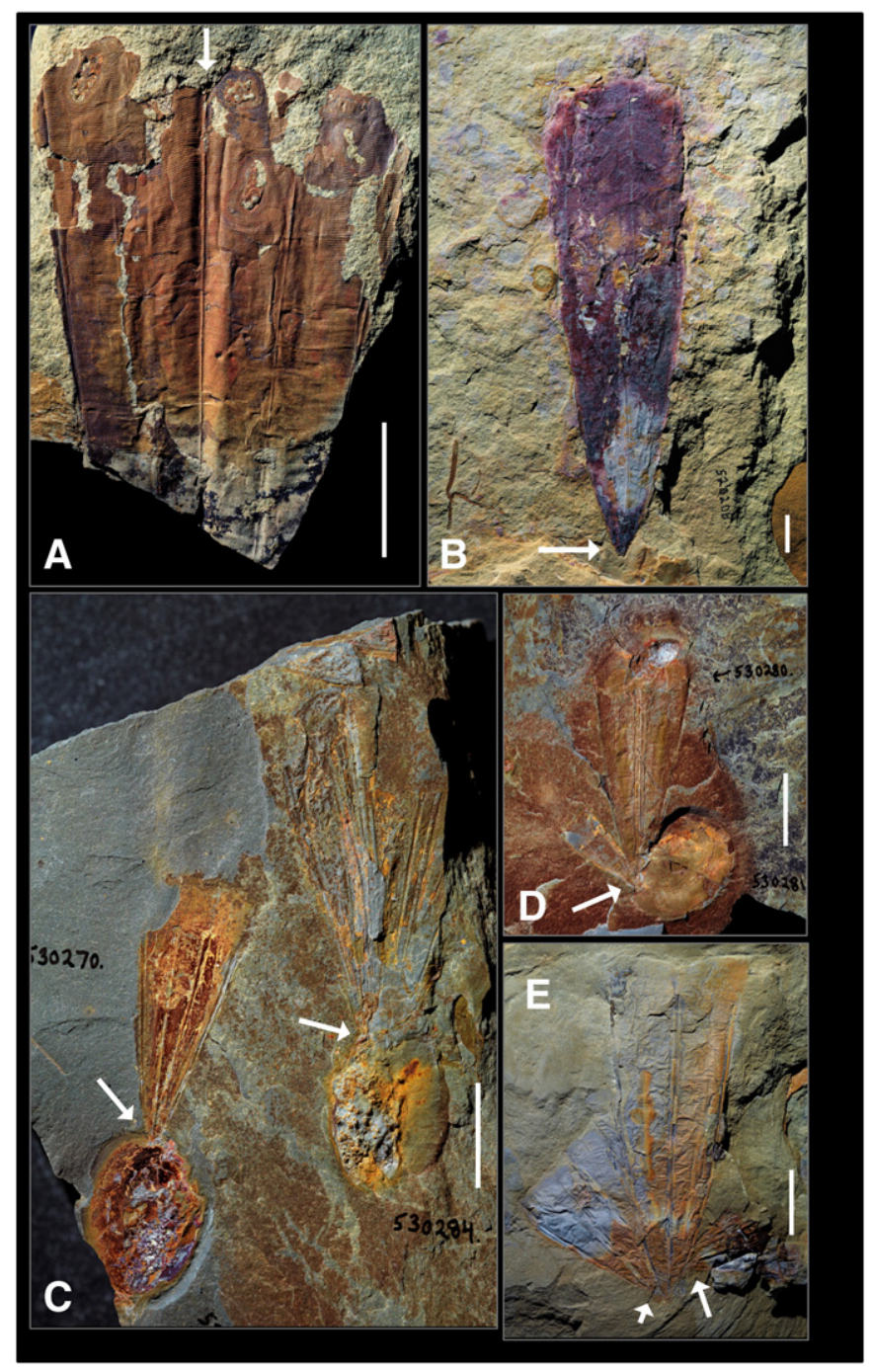

Fig. 3. Archaeoconularia sp. and Eoconularia sp. from the Fezouata Shale (TremadocianFloian) of southeastern Morocco (Core Gondwana; Anti-Atlas). A, Archaeoconularia sp. Single partial specimen (AA.BIZ12.03; lower EPF interval, late Tremadocian) clearly showing the transverse ornament (midline indicated by arrow). B, Archaeoconularia sp. Single nearly complete specimen (YPM 520208; upper EPF interval, mid Floian) preserving the arcuate apertural margin and broken just above the apex (arrow). C, Eoconularia sp. Single specimen (YPM 530270; left arrow) and a V-like pair (YPM 530283; left arrow), both originally attached at the apical end to a phosphatic brachiopod (arrows; lower EPF interval, late Tremadocian). D, Eoconularia sp. V-like pair (YPM 530280; lower EPF interval, late Tremadocian) composed of one small and one large specimen, both originally attached at their apical end to a phosphatic brachiopod (arrow). E, Eoconularia sp. Single nearly complete, relatively large specimen exhibiting two much smaller Eoconularia sp. arrayed along and possibly attached to one of its corners (long right arrow). Two additional, medium-sized specimens may be attached to another corner of the large specimen, closer to its apical end (short left arrow) (YPM 530272; lower EPF interval, late Tremadocian). Scale bars $=10 \mathrm{~mm}$.

found in the Tremadoc of Avalonia and Morocco (Table 1). Likewise, Sphenothallus is now known from the Tremadoc of Armorica and Morocco as well as from South China and North China, which were located closer to the palaeoequator than were either of the two other terranes (but South China was still close to Core Gondwana). It is intriguing that neither Archaeoconularia nor Eoconularia has been found in Armorica. A possible reason for this absence is that the Saint Chinian Formation strata that host $C$. azaisi differ lithologically from those of all other Lower Ordovician localities (Table 1), representing perhaps a palaeohabitat that was not suitable for other conulariids.

The Tremadocian conulariid assemblage of southeastern Morocco is most similar to that of Avalonia (Wales), with both assemblages consisting of one species each of Archaeoconularia and Eoconularia.

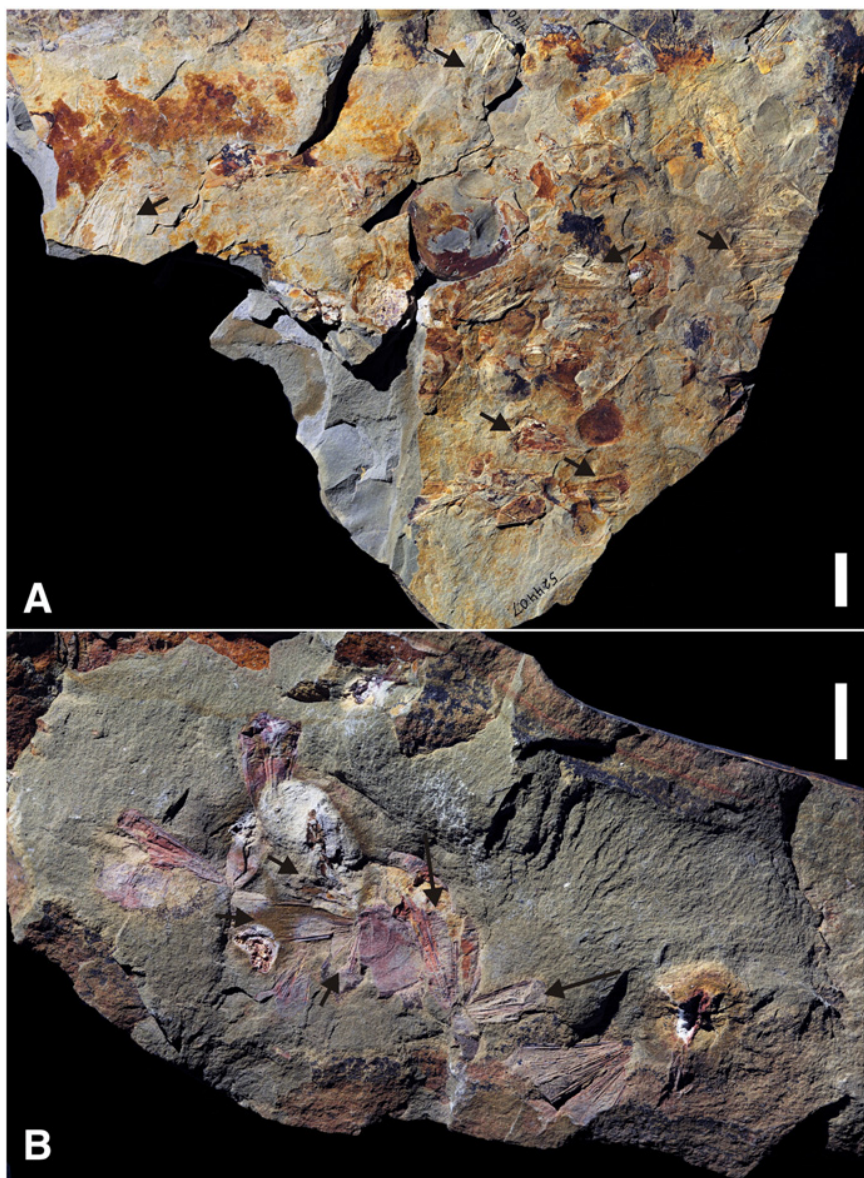

Fig. 4. Eoconularia sp. (Fezouata Shale, Anti-Atlas, southeastern Morocco). Examples of monospecific mass associations. A, Slab (YPM 524407; lower EPF interval, late Tremadocian) showing approximately 30 specimens (some indicated by arrows) in an area covering approximately $120 \mathrm{~cm}^{2}$. B, slab (YPM 530276; lower EPF interval, late Tremadocian) showing 10 specimens in an area covering approximately $30 \mathrm{~cm}^{2}$. The three specimens indicated by the short arrows form a radial cluster, and they converge on a common point situated within the margins of a phosphatic brachiopod. The two specimens indicated by the long arrows constitute a V-like pair likewise situated with the point of convergence of the component conulariid specimens located within the margins of a brachiopod. Scale bars $=10 \mathrm{~mm}$.

Exoconularia, known from the Floian of Wales but not from the Fezouata Shale, probably is a close relative of Archaeoconularia (Van Iten et al., 2014b; this paper, Fig. 1). Although Lower Ordovician strata of Wales have not yielded Sphenothallus, we predict that eventually they will.

Of the other terranes/localities, southeastern Morocco shares a single genus, Archaeoconularia, with Perunica, but no genera with Argentina, the Southern Montagne Noire (Armorica) or South China (Table 1). Moreover, Conularia has been found only in the Tremadocian-Floian of Perunica, and Conulariella in the Floian of this terrane and South China. The latter genus does occur in Middle Ordovician (Darriwilian) strata of Armorica (Armorican Massif; Van Iten et al., 2013), which also yield Archaeoconularia, Exoconularia, Metaconularia and Pseudoconularia (Spain; Sendino and Santos, 2011).

\section{Palaeoecology of conulariids}

\subsection{Monospecific mass occurrences}

A striking characteristic of Fezouata Shale Archaeoconularia sp. and Eoconularia sp., particularly of the latter species, is their great abundance and areal density compared with congeneric specimens from other Ordovician (and younger) terranes and rock units. Many of the Eoconularia specimens occur in monospecific mass associations 


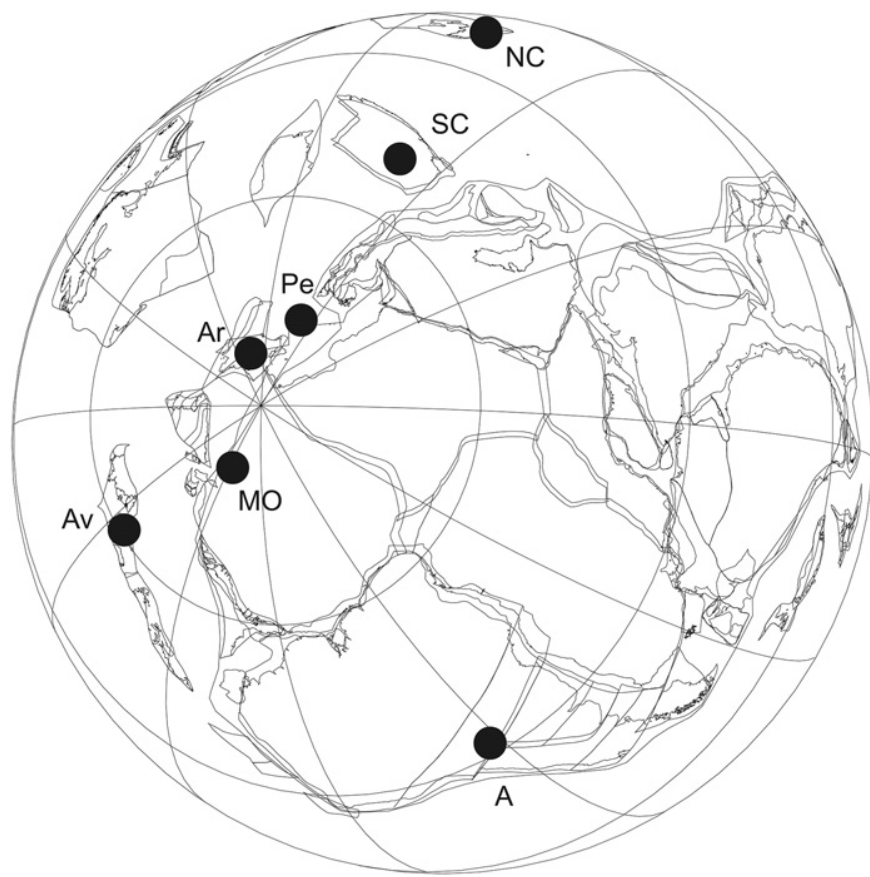

Fig. 5. Palaeogeographical distribution of Lower Ordovician conulariid and Sphenothallus localities. Oblique southern hemisphere view drawn for $\sim 495 \mathrm{Ma}$ (Tremadocian) using BugPlates (Torsvik, 2009) and with the position of South China modified following Cocks and Torsvik (2013). Terrane and other locality abbreviations: A, Argentina; Ar, Armorica (Southern Montagne Noire); Av, Avalonia (Wales); NC, North China (Korea); Pe, Perunica (Bohemia); SC, South China (Sandu, Guizhou Province); MO, southeastern Morocco.

consisting of up to approximately 50 specimens per $100 \mathrm{~cm}^{2}$ (Fig. 4). No such associations of this genus or other conulariids have previously been documented or reported, and HVI found none in museum collections of Eoconularia from other localities (e.g. Ordovician strata near Girvan, Scotland [collections of the Natural History Museum, London; Sendino and Darrell, 2008] and the Early Silurian Manitoulin Dolostone of Drummond Island, Michigan, USA [uncatalogued material in the collections of the University of Michigan Museum of Paleontology, Ann Arbor; Sinclair, 1948]). In short, the assemblages of Eoconularia sp. from the EPF-bearing intervals of the Fezouata Shale appear to contain the most abundant and densely packed specimens of this or any conulariid genus ever documented (see also discussion below).

The frequent occurrence of Archaeoconularia sp. and Eoconularia sp. in monospecific mass associations, in strata deposited in a low-energy environment well below fair-weather wave base (Martin et al., in press), suggests that the living conulariids were distributed in monospecific clumps or patches that were possibly clonal in origin (Van Iten and Cox, 1992; Rodrigues et al., 2006; Van Iten et al., 2012). Although the conulariids probably underwent limited transport (as indicated by the observation that they are now oriented parallel to bedding; Van Iten et al., 2012), the alternative hypothesis that clumping resulted from purely taphonomical factors seems unlikely, especially considering the occurrence of some specimens in V-like pairs (which probably would have been disrupted had they undergone appreciable transport). In general, biological processes leading to clumping constitute reproductive strategies, either sexual (i.e. settlement of planulae) or asexual (e.g. budding, settlement of pseudo-planulae). As discussed for example by Marques and Collins (2004), most medusozoan cnidarians have an asexual benthic stage in their life cycle. Within this stage, one or more of the following asexual modes of reproduction may occur: polyp budding (formation of modular organisms), profuse medusa budding (including scyphozoan strobilation), and dormant cyst production (podocysts, reinforcing seasonal maintenance of benthic populations) (Arai, 1997; Robinson et al., 2014). Medusozoans
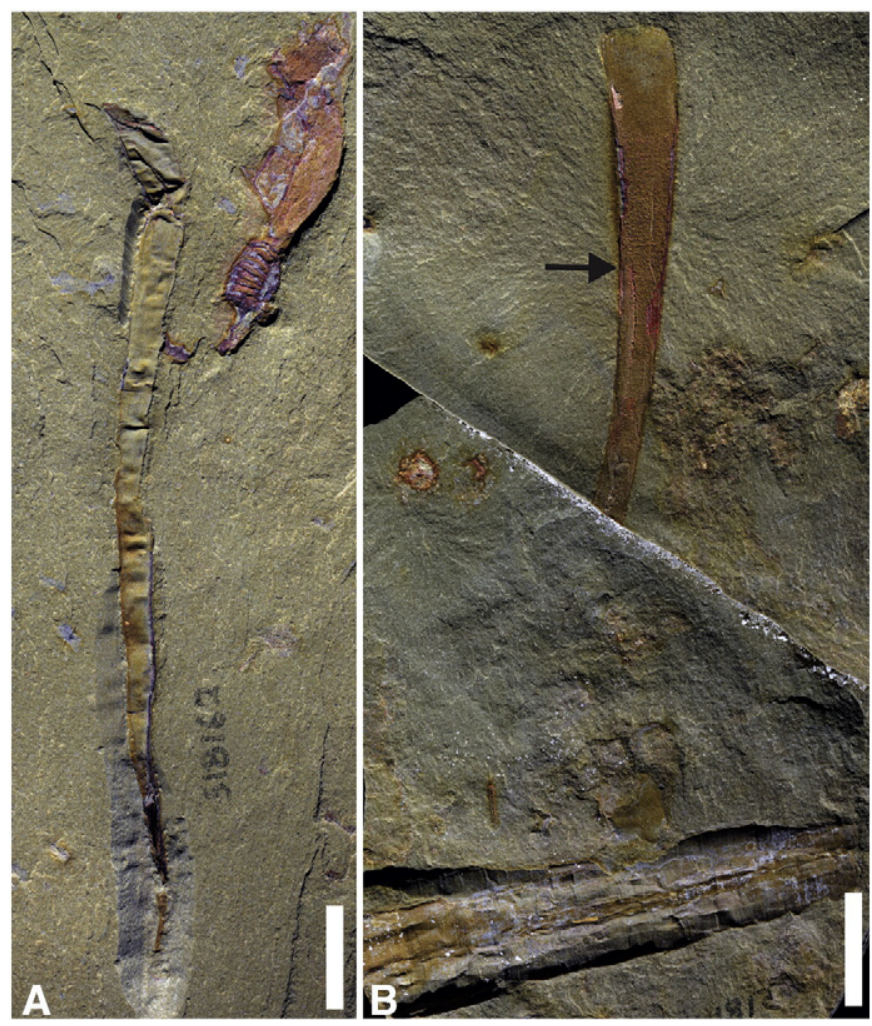

Fig. 6. Tubular phosphatic fossils from the Fezouata Shale (Tremadocian-Floian) of southeastern Morocco (Core Gondwana; Anti-Atlas), A, Sphenothallus sp. 1. Single slightly twisted and wrinkled specimen (YPM 518162; lower EPF interval, late Tremadocian) missing the apical holdfast. B, ?Sphenothallus sp. 2. Single specimen (YPM 518106; arrow; exact age uncertain) showing numerous fine, closely spaced transverse annulations. Scale bars $=10 \mathrm{~mm}$.

collectively exhibiting these reproductive modes/strategies are similar in morphology and clustering to Archaeoconularia and Eoconularia (see for example Miranda et al., 2012). In the conulariids, three scenarios could have led to biological clumping: a) attachment of groups (clusters) of conulariids to other species such as brachiopods or to other conulariids (see discussion below); b) clustering of individual conulariids that were not connected to biological substrates or to each other; or c) formation of clonal colonies, with each clump constituting a single integrated body.

\subsection{Conulariid/brachiopod associations}

Six of the specimens of Eoconularia sp. examined here form three V-like pairs (Van Iten et al., 2012), with the two members of each pair converging adapically toward a common point and nearly touching each other at the apical end (Fig. 3D, E). An additional six specimens form two radial clusters (Van Iten and Cox, 1992), each consisting of three specimens that converge adapically on a common point (Figs. $3 \mathrm{E}, 4 \mathrm{~B}$ ). Unfortunately, all of these specimens have been broken approximately one mm above the apex, which is now missing. Nevertheless, both members of one of the $V$-like pairs preserve their apertural margin, and one of these specimens is approximately three times longer than the other; furthermore, the point of convergence of the pair lies within the margins of a phosphatic brachiopod (Fig. 3D). The same is also true of one of the radial clusters (Fig. 4B). Eleven other Eoconularia specimens, four of them solitary and the rest arrayed in V-like pairs (e.g. Fig. 4B), form similar associations with a phosphatic brachiopod shell (Fig. 3C, E). In all 16 cases, the apicalmost portion of the conulariid lies immediately adjacent to the brachiopod and close to its commissural margin, and the long axis of the conulariid is inclined at a high angle to this margin. Also in all cases, brachiopod specimens are sparse 
(i.e. the areal density of brachiopods on the host slab is low). Importantly, similar conulariid/brachiopod associations, involving Conularia trentonensis Hall, 1847 and Onniella sp. (a rhynchonelliform brachiopod), occur in the Upper Ordovician (Katian) Collingwood Shale Formation of southwestern Ontario, Canada. For example, the small slab illustrated here in Fig. 7 bears three radial clusters, each composed of three Conularia converging on a common point. In all three clusters, the apical regions of the component conulariids lie directly beneath the shell of a single Onniella sp., a configuration that closely resembles that of the aforementioned Eoconularia sp. Together with the Eoconularia sp./phosphatic brachiopod associations, these are the first such intimate associations of conulariids and brachiopods ever documented (see discussion below).

The largest of the five Eoconularia sp. illustrated here in Fig. 3E exhibits two much smaller Eoconularia sp. arrayed along one of its corners. The two small specimens nearly touch the larger specimen at their apical ends (again broken just above the tip), and their long axes are aligned parallel to each other. On the other side of the large specimen, two additional, mutually parallel Eoconularia sp. appear to touch their larger neighbor, though closer to its apical end. This occurrence is highly similar to a conulariid/Sphenothallus association illustrated by Van Iten et al. (1996, pl. 1, fig. 8) and consisting of two mutually parallel
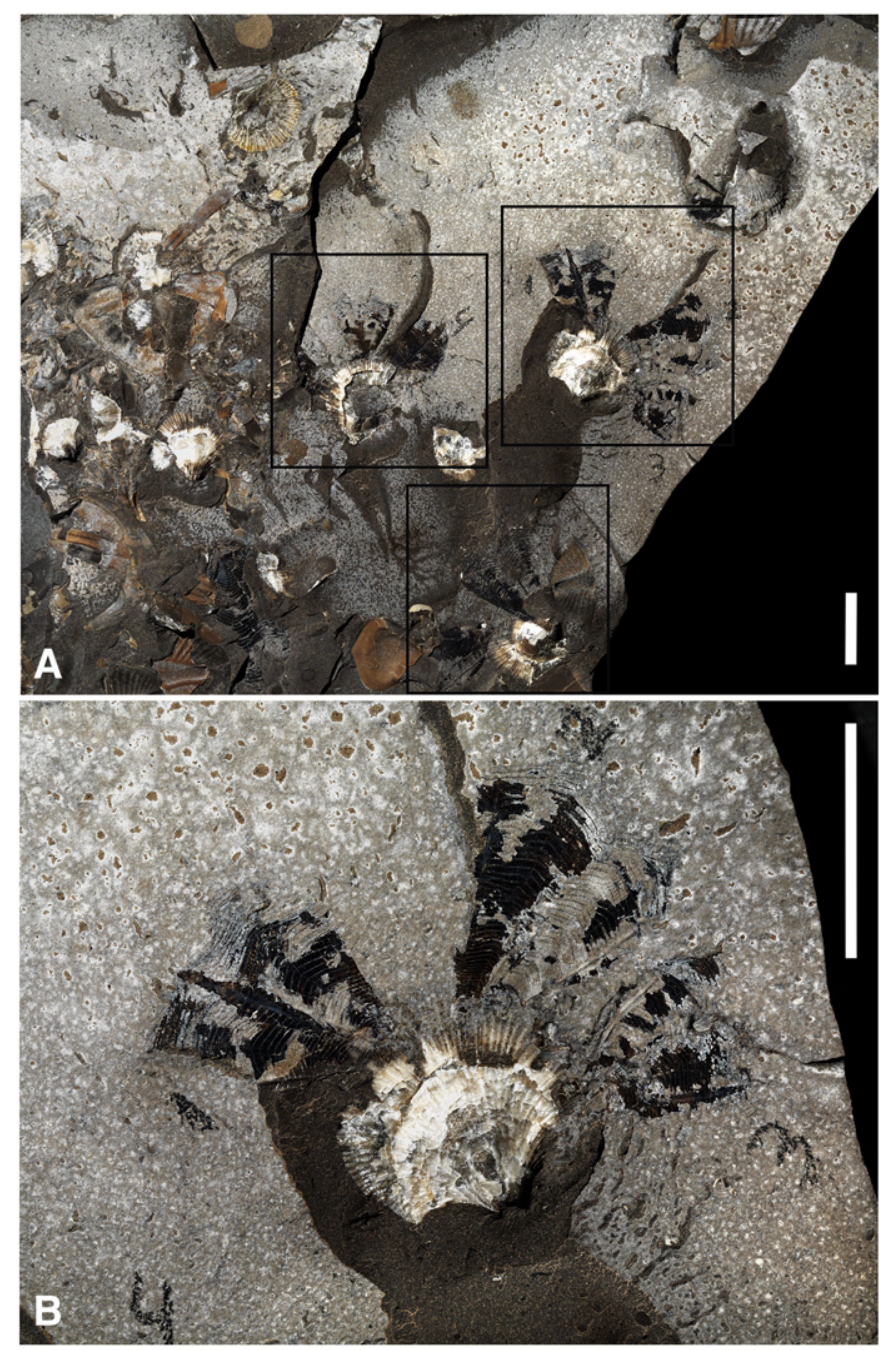

Fig. 7. Conularia trentonensis Hall, 1847 (Upper Ordovician [Katian], Collingwood Shale Formation, Lake Huron shoreline, southern Ontario, Canada; UMMP 73817). A, single bedding plane bearing three radial clusters (outlined by rectangular boxes), each composed of three conulariids originally attached to the shell of an Onniella sp. B, detail of one of the clusters. Scale bars $=10 \mathrm{~mm}$.
Climacoconus quadratus (Walcott, 1879) touching one of the longitudinal thickenings of the Sphenothallus tube.

Van Iten et al. (1996) argued that associations similar to those described above constitute compelling circumstantial evidence of original attachment of the conulariids to the associated fossils, probably at the apical end of the conulariids. Previously documented associations consist of one or more conulariids and the shell of a hyolith or nautiloid, a crinoid stem or Sphenothallus tube, or possible vertebrate bone (Van Iten and Südkamp, 2010; see also Van Iten et al., 1996 and references cited therein). Even though direct evidence of apical attachment is not evident (in all cases the tips of the conulariids are missing), it seems unlikely that such associations, with their multiple, spatial coincidences, are fortuitous or taphonomic in origin. This is particularly evident for the V-like pairs (Fig. 3D) and radial clusters (Fig. 7). The fact that the conulariids converge on a common point, situated within the margins of the brachiopod, tends to rule out the hypothesis that the fossils were brought together by bottom currents, as this mechanism requires either (a) multiple cases of originally solitary conulariids being deposited in such a way as to be contiguous at their apices, or (b) specimens originally arranged in V-like pairs and radial clusters undergoing transport without disruption of their original adapical convergence. Additionally, the low areal density of the specimens in question argues against these associations being merely fortuitous. Similar reasoning applies to the alternative hypothesis that the conulariid/brachiopod associations are an artifact of transport by biological agents. In short, then, it seems that the most likely explanation of multiple occurrences of conulariid/brachiopod associations such as those here documented, is that the spatial patterns now exhibited by these fossils reflect original attachment of the conulariids to brachiopod shells, most likely at the apical or adoral end of the conulariids. The same line of argument leads us to conclude that it is most probable that the two small Eoconularia sp. arrayed along a corner of a larger individual of this species (Fig. 3E), were originally attached or connected at their apex to the larger specimen. Moreover, because all three of these specimens are conulariids and members of the same species, it seems possible that the two small conulariids may not simply have been attached to the larger specimen, but rather budded from it. This hypothesis can potentially be corroborated by the discovery of specimens preserving the apex.

\section{Conclusions}

A literal reading of the fossil record of conulariids leads to the conclusion that this medusozoan clade underwent a radiation during Early Ordovician times. However, our cladistic analysis demonstrates that the two known pre-Ordovician genera, Baccaconularia (Furongian) and Paraconularia (latest Ediacaran), occupy apical positions in the conulariid tree (Fig. 1). If this interpretation is correct, then the most recent common ancestor of all conulariids originated still deeper within the Neoproterozoic Era, and therefore multiple conulariid ghost lineages extend downward through the Cambrian and Ediacaran periods. Rocks of the Cambrian System are widespread and have been sampled intensively, but thus far the only definitely known Cambrian conulariid locality (Hughes et al., 2000) has yielded but a single genus. Even the Cambrian Konservat-Lagerstätten have yet to produce a single specimen of a conulariid. Notwithstanding, the fact that the mid Cambrian Burgess Shale has yielded extremely rare Sphenothallus sp., a finely lamellar phosphatic taxon that appears to be isotaphonomic with conulariids, suggests that conulariids likewise may be present but extremely rare, occurring possibly as minute fragments (conulariid "microfossils"; Jerre, 1993; Van Iten et al., 1996, 2006b), which could be recovered by means of the same rock preparation techniques used for extraction of conodonts.

Conulariids and Sphenothallus in the EPF-bearing intervals of the Fezouata Shale of southeastern Morocco, introduced herein, represent the first records of these two medusozoan groups from the Lower 
Ordovician of Africa. Two genera of conulariids-Archaeoconularia and Eoconularia-are present, and there may also be two species of Sphenothallus (one smooth-walled and another with fine transverse ridges). Sample sizes for nearly all Lower Ordovician localities are relatively large ( $>30$ reposited specimens per species per locality), and thus differences in the taxonomic composition of conulariids between Morocco and the four other Lower Ordovician localities (Argentina, Armorica, Perunica and South China) may reflect differences in the original palaeoenvironments and/or factors promoting faunal endemism. Archaeoconularia and Eoconularia are also present in the Lower Ordovician of Wales (Avalonia), which was located adjacent to northwestern Africa; however, the sample sizes available for the Avalonian sites are much smaller than for other palaeocontinents. Thus, there may be significant undiscovered conulariid diversity in Avalonia.

In addition to being relatively diverse, Lower Ordovician conulariids may also be locally abundant. In the Fezouata Shale, Archaeoconularia sp. and Eoconularia sp. commonly occur in monospecific mass associations, with observed Eoconularia sp. concentrations containing up to about 50 specimens in an area of approximately $100 \mathrm{~cm}^{2}$, on the same bedding plane/lamina. Moreover, some Eoconularia sp., including specimens forming V-like pairs, show orientational evidence of original apical attachment to phosphatic brachiopods and even to other Eoconularia sp. Similar evidence of original apical attachment to rhynchonelliform brachiopods (Onniella sp.) is exhibited by radially clustered $C$. trentonensis from the Upper Ordovician Collingwood Shale of Ontario, Canada. This is the first time that evidence of original apical attachment of conulariids to brachiopods or to other conulariids has been documented. Finally, even though most conulariids and Sphenothallus in the EPF-bearing intervals of the Fezouata Shale probably underwent limited (local) transport immediately prior to final burial, the present occurrence of Archaeoconularia sp. and Eoconularia sp. in monospecific mass associations probably reflects an original clumped distribution of these two conulariids on the shallow seafloor.

\section{Acknowledgments}

Financial support for this project was provided by a major research grant from the Hanover College Faculty Development Committee to HVI. For permission to examine and/or borrow reposited conulariid and Sphenothallus specimens we thank S. Butts (Yale University Peabody Museum), D. Miller (University of Michigan Museum of Paleontology), J. Darrell (Natural History Museum), B. Lefebvre (University of Lyon) and L. McCobb (National Museum of Wales). We also thank B. Lefebvre and P. Van Roy for photographing specimens in collections of the Universities of Lyon and Montpellier, France (BL) and the Yale University Peabody Museum (PVR), and J. Utrup for assistance in examining Fezouata Shale specimens in the collections of the Yale University Peabody Museum. P. Van Roy read an earlier version of this article. Constructive comments by two anonymous reviewers are greatly appreciated. Finally, the single Sphenothallus specimen from the Southern Montagne Noire was collected by J. Botting (National Museum of Wales).

\section{Appendix A. Supplementary data}

Supplementary data to this article can be found online at http://dx. doi.org/10.1016/j.palaeo.2016.03.008.

\section{References}

Arai, M.N., 1997. A Functional Biology of Scyphozoa. Chapman and Hall, London, UK (295 pp.).

Barrande, J., 1867. Système Silurien du centre de la Bohême. Iière Partie. Tome 3. Classe des mollusques, ordre des ptéropodes. Charles Bellmann, Prague (179 pp.).

Bouček, B., 1928. Révision des Conulaires paléozoïques de la Bohême. Palaeontographica Bohemiae XI (108 pp.).
Bouček, B., 1939. Conularida. In: Schindewolf, O.H. (Ed.), Handbuch der Paläozoologie, Band 2A. Gebrüder Borntraeger, Berlin, pp. A113-A131.

Caron, J.-B., Jackson, D.A., 2008. Paleoecology of the Greater Phyllopod Bed community, Burgess Shale. Palaeogeogr. Palaeoclimatol. Palaeoecol. 258, 222-256.

Choi, D.K., 1990. Sphenothallus ("Vermes") from the Tremadocian Dumugol Formation, Korea. J. Paleontol. 64, 403-408.

Cocks, L.R.M., Torsvik, T.H., 2004. Major terranes in the Ordovician. In: Webby, B.D., Paris, F., Droser, M.L., Percival, I.G. (Eds.), The Great Ordovician Biodiversification Event. Columbia University Press, New York, pp. 61-67.

Cocks, L.R.M., Torsvik, T.H., 2013. The dynamic evolution of the Palaeozoic geography of eastern Asia. Earth Sci. Rev. 117, 40-79.

Collins, A.G., Schuchert, P., Marques, A.C., Jankowski, T., Medina, M., Schierwater, B., 2006. Medusozoan phylogeny and character evolution clarified by new large and small subunit rDNA data and an assessment of the utility of phylogenetic mixture models. Syst. Biol. 55, 97-115.

Cope, J.C.W., 1996. Early Ordovician (Arenig) bivalves from the Llangynog Inlier, South Wales. Palaeontology 39, 979-1025.

Cope, J.C.W., 2005. Octocorallian and hydroid fossils from the Lower Ordovician of Wales. Palaeontology 48, 433-445.

Destombes, J., Hollard, H., Willefert, S., 1985. Lower Palaeozoic rocks of Morocco. In: Holland, C.H. (Ed.), Lower Paleozoic Rocks of North-western and West-central Africa. Wiley, New York, Chichester, Brisbane, pp. 91-336.

Ebbestad, J.O.R., Högström, A.E.S., 2007. Ordovician of the Siljan District, Sweden. In: Ebbestad, J.O.R., Wickström, L., Högström, A.E.S. (Eds.), WOGOGOB 2007, 9th Meeting of the Working Group on the Ordovician Geology of Baltoscandia, Field Guide and Abstracts. Geological Survey of Sweden, Uppsala, pp. 7-26.

Fatka, O., Kraft, P., 2013. Sphenothallus Hall, 1847 from Cambrian of Skryje-Týřovice Basin (Barrandian area, Czech Republic). Ann. Soc. Geol. Pol. 83, 309-315.

Ford, R.C., Van Iten, H., Clark III, G.R., 2016. Microstructure and composition of the periderm of conulariids. J. Paleontol. (in press).

A revised correlation of Ordovician rocks in the British Isles. In: Fortey, R.A., Harper, D.A.T., Ingham, J.K., Owen, A.W., Parkes, M.A., Rushton, A.W.A., Woodcock, N.H. (Eds.), Geological Survey Special Report No. 24 (83 pp.).

Gutiérrez Marco, J.C., Martin, E., 2016. Biostratigraphy and palaeogeography of Lower Ordovician graptolites from the Fezouata Shale (Moroccan Anti-Atlas). Palaeogeogr. Palaeoclimatol. Palaeoecol. 460, 35-49 (in this issue).

Hall, J., 1847. Paleontology of New-York. Volume I. Containing Descriptions of the Organic Remains of the Lower Division of the New-York System (Equivalent to the Lower Silurian Rocks of Europe). C. Van Benthuysen, Albany (338 pp.).

Hessland, I., 1949. A Lower Ordovician Pseudoconularia from the Siljan District. Bulletin of the Geological Institutes of the University of Uppsala 33, pp. 429-436.

Holm, G., 1893. Sveriges Kambrisk-Siluriska Hyolithida och Conulariidae. Sveriges Geologiska Undersokning, Afhandlingar och Uppsatser, Stockholm, Series C 112, pp. 1-172.

Hughes, N.C., Gunderson, G.O., Weedon, M.J., 2000. Late Cambrian conulariids from Wisconsin and Minnesota. J. Paleontol. 74, 828-838.

Jerre, F., 1993. Conulariid microfossils from the Silurian lower Visby Beds of Gotland, Sweden. Palaeontology 36, 403-424.

Jerre, F., 1994. Anatomy and phylogenetic significance of Eoconularia loculata, a conulariid from the Silurian of Gotland. Lethaia 27, 97-109.

Kraft, P., Kraft, J., 2003. Facies of the Klabava Formation (?Tremadoc-Arenig) and their fossil content (Barrandian area, Czech Republic). INSUGEO, Serie Correlación Geológica 17, pp. 309-314.

Kröger, B., Evans, D.H., 2011. Review and palaeoecological analysis of the late Tremadocian-early Floian (Early Ordovician) cephalopod fauna of the Montagne Noire, France. Fossil Rec. 14, 5-34.

Leme, J.M., Heredia, S., Rodrigues, S.C., Simões, M.G., Aceñolaza, G.F., Milana, J.P., 2003. Teresconularia gen. nov. from the Lower Ordovician of the Cordillera Oriental of Salta (NW Argentina): the oldest conulariid (Cnidaria) from South America. Rev. Esp. Micropaleontol. 35, 265-273.

Leme, J.M., Simões, M.G., Marques, A.C., Van Iten, H., 2008. Cladistic analysis of the suborder Conulariina Miller and Gurley, 1896 (Cnidaria, Scyphozoa; Vendian-Triassic). Palaeontology 51, 649-662.

Li, G.-X., Zhu, M.-Y., Van Iten, H., Li, C.-W., 2004. Occurrence of the earliest known Sphenothallus Hall in the Lower Cambrian (Qiongzhusian and Canglanpuan stages) of southern Shaanxi Province, South China. Geobios 37, 229-237.

Marques, A.C., Collins, A.G., 2004. Cladistic analysis of Medusozoa and cnidarian evolution. Invertebr. Biol. 123, 23-42.

Martin, E.L.O., Pittet, B., Gutiérrez-Marco, J.-C., Lefebvre, B., Vannier, J., El Hariri, K., Lerosey-Aubril., R., Masrour, M., Nowak, H., Servais, T., Vandenbroucke, T.R.A., Van Roy, P., Vaucher, R., 2016. The Lower Ordovician Fezouata Konservat-Lagerstätte from Morocco: age, environment and evolutionary perspectives. Gondwana Res. http://dx.doi.org/10.1016/j.gr.2015.03.009 (in press).

Mergl, M., 1997. New and rare lingulate brachiopods from lower part of the Klabava Formation (Arenig, Lower Ordovician) of Prague Basin, Bohemia. J. Czech Geol. Soc. 42, 95-104.

Miller, S.A., Gurley, W.F.E., 1896. New species of Palaeozoic invertebrates from Illinois and other states. Illinois State Museum Natural History Bulletin 11, pp. 1-50.

Miranda, L.S., Morandini, A.C., Marques, A.C., 2012. Do Staurozoa bloom? A review of stauromedusan population biology. Hydrobiologia 690, 57-67.

Mortin, J. 1986. Studies on the Conulariida. Unpublished Ph.D. thesis, University of Wales (Swansea), $384 \mathrm{pp}$

Muscente, A.D., Xiao, S., 2015. New occurrences of Sphenothallus in the lower Cambrian of South China: implications for its affinities and taphonomic demineralization of shelly fossils. Palaeogeogr. Palaeoclimatol. Palaeoecol. 437, 141-164. 
Noffke, N., Nitsche, E., 1994. Sedimentology of Lower Ordovician clastic shelf deposits, Montagne Noire (France). Géol. Fr. 4, 3-19.

Nysæther, E., Torsvik, T.H., Feist, R., Walderhaug, H.J., Eide, E.A., 2002. Ordovician palaeogeography with new palaeomagnetic data from the Montagne Noire (Southern France). Earth Planet. Sci. Lett. 203, 329-341.

Overstreet, R.B., Oboh-Ikuenobe, F.E., Gregg, J.M., 2003. Sequence stratigraphy and depositional facies of Lower Ordovician cyclic carbonate rocks, southern Missouri, USA. J. Sediment. Res. 73, 421-433.

Robinson, K., Ruzicka, J., Decker, M.B., Brodeur, R., Hernandez, F., Quiñones, J., Acha, M., Uye, S., Mianzan, H., Graham, W., 2014. Jellyfish, forage fish, and the world's major fisheries. Oceanography 27, 104-115. http://dx.doi.org/10.5670/oceanog.2014.90.

Rodrigues, S.C., Leme, J.M., Simões, M.G., 2006. Significado paleobiológico de agrupamentos (coloniais/gregários) de Conularia quichua Ulrich 1890 (Cnidaria), Formação Ponta Grossa, Devoniano (Pragiano-Emsiano), Bacia do Paraná, Brasil. Ameghiniana 43, 273-284.

Rushton, A.W.A., Howells, M.F., 1998. Stratigraphical framework for the Ordovician of Snowdonia and the Lleyn Peninsula. British Geological Survey Research Report, RR/99/08 (41 pp.).

Salter, J.W., 1866. Appendix on the fossils. In: Ramsay, A.C. (Ed.), Geology of North Wales, Volume 1, Part 3. Geological Survey of Great Britain, Memoir, pp. 239-363.

Sendino, C., Darrell, J., 2008. The collection of conulariids in the Natural History Museum of London. Geol. Curator 9, 3-20.

Sendino, C., Santos, C., 2011. Taxonomical revision of conulariids in the collection of the Museo Nacional de Ciencias Naturales (CSIC), Madrid (Spain). Graellsia 67, 13-21.

Sinclair, G.W., 1940. The genotype of Conularia. Can. Field. Nat. 54, 72-74.

Sinclair, G.W., 1944. A new genus of Conularids. Can. Field. Nat. 57, 123.

Sinclair, G.W. 1948. The biology of the Conularida. Unpublished Ph.D. thesis, McGill University (Montréal), 442 pp.

Sinclair, G.W., 1952. A classification of the Conularida. Fieldiana Geol. 10, 135-145.

Slater, I., 1907. A monograph of the British Conularidae. Monogr. Palaeontogr. Soc. 61 $1-40$.

Sowerby, J., 1821. The Mineral Conchology of Great Britain; or Coloured Figures and Descriptions of those Remains of Testaceous Animals or Shells, Which Have Been Preserved at Various Times, and Depths in the Earth. W. Arding Co., London (194 pp.).

Swofford, D.L., 2003. PAUP*. Phylogenetic Analysis Using Parsimony (and Other Methods). Version 4. Sinauer Associates, Sunderland, Massachusetts.

Thoral, M., 1935. Contribution á l'étude paléontologique de l'Ordovicien inférieur de la Montagne Noire, et revision sommaire de la faune Cambrienne de la Montagne Noire Thèse de Doctorat d'État de l'Université de Paris Imprimerie de La Charité, Montpellier (362 pp.).

Torsvik, T.H., 2009. BugPlates: Linking Biogeography and Palaeogeography. Available online at http://www.geodynamics.no/Web/Content/Software (accessed 5 June 2010).

Tortello, M.F., Vizcaïno, D., Álvaro, J.J., 2006. Early Ordovician agnostoid trilobites from the southern Montagne Noire, France. J. Paleontol. 80, 477-495.

Van Iten, H., 1992. Microstructure and growth of the conulariid test: implications for conulariid affinities. Palaeontology 35, 359-372.

Van Iten, H., Cox, R.S., 1992. Evidence of clonal budding in a radial cluster of Paraconularia crustula (White) (Pennsylvanian: ?Cnidaria). Lethaia 25, 421-426.

Van Iten, H., Südkamp, W., 2010. Exceptionally preserved conulariids and an edrioasteroid from the Hunsrück Slate (Lower Devonian, SW Germany). Palaeontology 53, 403-414.
Van Iten, H., Vhylasova, Z., 2004. Conulariids. In: Webby, B.D., Paris, F., Droser, M.L. Percival, I.G. (Eds.), The Great Ordovician Biodiversification Event. Columbia University Press, New York, pp. 119-123.

Van Iten, H., Leme, J.M., Simões, M.G., Marques, A., Collins, A., 2006a. Reassessment of the phylogenetic position of conulariids in the subphylum Medusozoa (phylum Cnidaria). J. Syst. Palaeontol. 4, 109-118.

Van Iten, H., Lichtenwalter, M., Leme, J.M., Simões, M.G., 2006b. Possible taphonomic bias in the preservation of phosphatic macroinvertebrates in the uppermost Maquoketa Formation (Upper Ordovician) of northeastern Iowa (north-central USA). J. Taphon. 4, 207-220.

Van Iten, H., Burkey, M.H., Leme, J.M., Marques, A.C., 2014b. Cladistics and mass extinctions: the example of conulariids (Scyphozoa, Cnidaria) and the End Ordovician Extinction Event. GFF 136, 275-280.

Van Iten, H., Cox, R.S., Mapes, R.H., 1992. New data on the morphology of Sphenothallus Hall: implications for its affinities. Lethaia 25, 135-144.

Van Iten, H., Fitzke, J.A., Cox, R.S., 1996. Problematical fossil cnidarians from the Upper Ordovician of the north-central USA. Palaeontology 39, 1037-1064.

Van Iten, H., Marques, A.C., Leme, J.M., Pacheco, M.L.A.F., Simões, M.G., 2014a. Origin and early evolution of the phylum Cnidaria Verrill: major developments in the analysis of the taxon's Proterozoic-Cambrian history. Palaeontology 57, 677-690.

Van Iten, H., Muir, L.A., Botting, J.P., Zhang, Y.-D., Lin, J.-P., 2013. Conulariids and Sphenothallus (Cnidaria, Medusozoa) from the Tonggao Formation (Lower Ordovician, China). Bull. Geosci. 88, 713-722.

Van Iten, H., Tollerton Jr., V.P., Ver Straeten, C.A., Leme, J.M., Simões, M.G., Rodrigues, S.C. 2012. Life mode of in situ Conularia in a Middle Devonian epibole. Palaeontology 55, $1-20$.

Van Iten, H., Zhu, M.-Y., Collins, D., 2002. First report of Sphenothallus Hall, 1847 in the Middle Cambrian. J. Paleontol. 76, 902-905.

Van Iten, H., Zhu, M.-Y., Li, G.-X., 2010. Redescription of Hexaconularia He and Yang, a small shelly fossil from the lower Cambrian of China. Palaeontology 53 (191), 199.

Van Roy, P., Briggs, D.E.G., Gaines, R.R., 2015. The Fezouata fossils of Morocco - an extraordinary record of marine life in the Early Ordovician. J. Geol. Soc. 172, 541-549.

Van Roy, P., Orr, P.J., Botting, J.P., Muir, L.A., Vinther, J., Lefebvre, B., El Hariri, K., Briggs, D.E.G., 2010. Ordovician faunas of Burgess Shale type. Nature 465, 215-218.

Vizcaino, D., Álvaro, J.J., Lefebvre, B., 2001. The Lower Ordovician of the southern Montagne Noire. Annales de la Société Géologique du Nord ( $2^{\mathrm{e}}$ série) 8, pp. 213-220.

Walcott, C.D., 1879. Descriptions of new species of fossils from the Trenton limestone. New York State Museum of Natural History, 28th Annual Report, pp. 93-97.

Wiman, C., 1895. Paleontologische Notizen 1-2. Conularia loculata n. sp. University of Uppsala, Geological Institution, Bulletin 2, pp. 113-117.

Želízko, J.V., 1911. Neue Pteropoden des älteren Paläozoikums Mittelböhmens. Jahrbuch der Kaiserlich-königlichen geologischen Reichanstalt 61, pp. 41-52.

Želízko, J.V., 1921. Äquivalente der untersilurichen Euloma-Nioba fauna bei Plzenec in Böhmen. Videnskabs-selskabet i Christiania, Matematisk-naturvidenskabelig Klasse, Skrifter 2, pp. 1-27.

Zhao, F.-C., Zhu, M.-Y., Hu, S.-X., 2010. Community structure and composition of the Cambrian Chengjiang biota. Sci. China Earth Sci. 53, 1784-1799.

Zhu, M.-Y., Van Iten, H., Cox, R.S., Zhao, Y.-L., Erdtmann, B.D., 2000. Occurrence of Byronic Mathew and Sphenothallus Hall in the Lower Cambrian of China. Palaeontol. Z. 74 227-238. 